\title{
Increased IgG Rheumatoid Factor-Positivity in the Asian Rheumatoid Arthritis Patients Irrespective of Ethnicity
}

\author{
Chun Lai Too ${ }^{1,2 *}$, Johan Rönnelid ${ }^{2,3}$, Yuslina Mat Yusoff ${ }^{1}$, Jasbir Singh Dhaliwal ${ }^{1}$, Nor Ashikin Jinah ${ }^{1}$, \\ Abqariyah Yahya ${ }^{1}$, Heselynn Hussien ${ }^{4}$, Wahinuddin Sulaiman ${ }^{5}$, Per Tobias Larsson ${ }^{2}$, Shahnaz Murad ${ }^{1}$ \\ ${ }^{1}$ Institute for Medical Research, Kuala Lumpur, Malaysia; ${ }^{2}$ Rheumatology Unit, Department of Medicine, Karolinska Institutet, \\ Stockholm, Sweden; ${ }^{3}$ Department of Immunology, Genetics and Pathology, Uppsala University, Uppsala, Sweden; ${ }^{4}$ Department of \\ Medicine, Putrajaya Hospital, Wilayah Persekutuan, Malaysia; ${ }^{5}$ Department of Medicine, Hospital Raja Perempuan Bainun, Ipoh, \\ Malaysia. \\ Email: ${ }^{\text {toocl@imr.gov.my }}$
}

Received November 24 ${ }^{\text {th }}, 2013$; revised December $24^{\text {th }}, 2013$; accepted December $31^{\text {st }}, 2013$

Copyright (C) 2014 Chun Lai Too et al. This is an open access article distributed under the Creative Commons Attribution License, which permits unrestricted use, distribution, and reproduction in any medium, provided the original work is properly cited. In accordance of the Creative Commons Attribution License all Copyrights (C) 2014 are reserved for SCIRP and the owner of the intellectual property Chun Lai Too et al. All Copyright (c) 2014 are guarded by law and by SCIRP as a guardian.

\section{ABSTRACT}

Aim of Work: Initial observations implied IgG rheumatoid factor (RF) to be common among Malaysian rheumatoid arthritis (RA) patients. We tested this hypothesis and used a multiethnic RA cohort (Malays, Chinese and Indians) to investigate whether the IgG RF predominance might be genetically or environmentally determined. Patients and Methods: 556 serum samples comprising 171 patients classified as RA according to the 1987 ACR criteria, 60 patients with other rheumatic diseases and 325 non-rheumatic controls were tested for IgG RF, IgM RF and anti-CCP by ELISA. The findings were then tested in a larger RA case-control cohort $(n=1844)$. Results: IgG RF predominated over IgM RF in all the investigated ethnic groups. The sensitivity, specificity, and diagnostic accuracy of IgG RF (55.6\%, 91.2\% and 80.2\%, respectively) were superior compared to IgM RF, but comparable to anti-CCP. IgG RF was however, also increased in the Malaysian controls, but the IgG RF superiority over IgM RF was still apparent after cutoff adjustment according to the 1987 ACR criteria. Autoantibody levels did not differ between the three ethnic groups. The Receiver Operating Characteristics (ROC) curves showed larger areas under the curves for IgG RF (0.826) and for anti-CCP (0.867) than for IgM RF (0.737). Review of the literature showed consistently higher sensitivity for IgG RF in studies of Asian RA patients as compared to Caucasian and African-American studies. Conclusion: Increased frequency of IgG RF-positive in RA populations with different genetic background living in Malaysia argues for an environmental factor selectively amplifying the IgG RF response.

\section{KEYWORDS}

Rheumatoid Arthritis (RA); IgG RF; IgM RF; Anti-Cyclic Citrullinated Peptide (Anti-CCP); Asia; Ethnicity

\section{Introduction}

Rheumatoid arthritis (RA) is a systemic autoimmune disease affecting $0.5 \%$ to $1 \%$ of the global population [1-3]. It is characterized by chronic inflammation, which generally leads to progressive joint destruction and consequent disability and reduction of quality of life if not treated promptly and adequately [1-3]. Recent evidence suggests that early intervention is crucial in preventing irreversible joint damage. Thus, it is important to diag-

*Corresponding author. nose RA at an early stage $[4,5]$.

Until very recently, the diagnostic classification of RA has been based on the 1987 American College of Rheumatology (ACR) revised criteria, which includes rheumatoid factor (RF), clinical and radiological criteria [6]. RFs can be detected in $60 \%$ to $80 \%$ of the patients with RA [2,7]. IgM is the most frequently studied RF isotype and also most commonly measured in clinical laboratories. It is also the most common RF isotype in Caucasian RA populations [8,9]. Some studies have implicated IgA RF as especially associated with extra-articular RA and 
with erosive RA [10]. Simultaneous detection of IgM and IgA RF has been shown to be highly specific for RA in Iceland [8]. While IgG RF has a lower specificity than the other isotypes in the Caucasian RA populations [8,9], it has been implicated in RA patients with nodules [11], vasculitis [12,13] and hyperviscosity syndrome [14]. Generally, much less is known about the importance of IgA and IgG RF in chronic disease [7].

Initial observations in our laboratory implied IgG RF to be common among Malaysian patients with RA. As the Malaysia population consists of three major ethnic groups with different genetic backgrounds, but sharing the same general environment, we carried out this study to test the hypothesis that the prevalence of IgG RF might be increased in Malaysia and to investigate whether any increase in IgG RF would be general or limited to the major population of Malaysia, the Malays. We also investigated the presence of anti-cyclic citrullinated peptide antibody (ACPA) by using the anti-cyclic citrullinated peptide (anti-CCP) antibodies kits, as ACPA have been included together with RF in the serology domain of the new EULAR/ACR RA classification criteria [15].

\section{Patients and Methods}

A total of 556 subjects were enrolled in the study between July 2005 and July 2007. Serum samples were obtained from 171 consecutively enrolled patients with RA, 60 patients with other rheumatic diseases and 325 non-rheumatic controls. All serum samples were stored at $-20^{\circ} \mathrm{C}$ until assayed. These three sample groups were used as the initially investigated cohort (henceforth named the first set). An independent set of serum samples were collected from 886 patients with RA and 958 controls from the Malaysian Epidemiological Investigation of Rheumatoid Arthritis (MyEIRA) case-control study and were used for replication (second set) of the initial findings. In the replication study population, the median disease duration for RA was one year (inter quartile range, IQR $=2$ years). The total number of 1844 individuals in this replication study is part of the 1079 RA cases and 1470 healthy controls, included in recently published paper [16], where RF isotypes were not investigated.

Table 1 shows the baseline demographic characteristics of the subjects recruited for this study. In the first set study, all the patients with RA and other rheumatic diseases were recruited from three government rheumatology clinics in Malaysia. All RA cases were diagnosed by rheumatologists according to the 1987 ACR classification criteria [6]. The disease duration for RA at the time of blood sampling was stratified into two groups: $<2$ years and $>2$ years. Radiological findings were recorded
Table 1. Baseline demographic characteristics of rheumatoid arthritis, other rheumatic diseases and non-rheumatic controls.

\begin{tabular}{|c|c|c|c|}
\hline & RA & $\begin{array}{l}\text { Other rheumatic } \\
\text { diseases }\end{array}$ & $\begin{array}{l}\text { Non-rheumatic } \\
\text { controls }\end{array}$ \\
\hline \multicolumn{4}{|c|}{ Initially investigated cohort (first set) } \\
\hline Samples size (n) & 171 & 60 & 325 \\
\hline Females (\%) & 150 (87.7) & 49 (81.7) & $273(84.0)$ \\
\hline $\begin{array}{l}\text { Age: mean } \pm \text { SD } \\
\text { (years) }\end{array}$ & $47.8 \pm 11.6$ & $40.2 \pm 13.3$ & $46.2 \pm 11.5$ \\
\hline \multicolumn{4}{|l|}{ Ethnicity (n) (\%) } \\
\hline Malay & $92(53.8)$ & $37(61.2)$ & $179(55.1)$ \\
\hline Chinese & $31(18.1)$ & $12(20.0)$ & $62(19.1)$ \\
\hline Indian & $39(22.8)$ & 8 (13.3) & $67(20.6)$ \\
\hline Others & $9(5.3)$ & $3(5.0)$ & $17(5.2)$ \\
\hline \multicolumn{4}{|c|}{ Disease duration $(\mathrm{n}=171)$} \\
\hline$<2$ years $(\%)$ & $124(72.5)$ & - & - \\
\hline$>2$ years $(\%)$ & $47(27.5)$ & - & - \\
\hline \multicolumn{4}{|c|}{ Radiographic characterization $(\mathrm{n}=117$ ) } \\
\hline Erosive (\%) & $38(32.5)$ & & \\
\hline Non-erosive (\%) & $79(67.5)$ & & \\
\hline \multicolumn{4}{|c|}{ Replication cohort (second set) } \\
\hline Samples size (n) & 886 & - & 958 \\
\hline Female (\%) & $752(84.9)$ & - & $862(89.9)$ \\
\hline $\begin{array}{l}\text { Age: mean } \pm \text { SD } \\
\text { (years) }\end{array}$ & $48.2 \pm 11.7$ & - & $47.7 \pm 11.4$ \\
\hline \multicolumn{4}{|l|}{ Ethnicity (n) (\%) } \\
\hline Malay & $355(40.1)$ & - & $603(62.9)$ \\
\hline Chinese & 191 (21.6) & - & $122(12.7)$ \\
\hline Indian & 278 (31.4) & - & 178 (18.6) \\
\hline Others & 62 (6.9) & - & $55(5.7)$ \\
\hline
\end{tabular}

RA: rheumatoid arthritis; SD: standard deviation.

as absence or presence of hand joint erosions. Radiographic erosion data was available for 117 of 171 (68.4\%) of the patients with RA. Out of these, 73 of 117 (62.4\%) were diagnosed within less than two years of first joint symptoms.

The diagnosis in the rheumatological control group were systemic lupus erythematosus (SLE; $n=28$ ), psoriatic arthritis (PSA; $n=9$ ), osteoarthritis $(n=8)$, gouty arthritis ( $\mathrm{n}=3)$, mixed connective tissue disease (MCTD; $n=3$ ), reactive arthritis $(n=2)$, scleroderma (Sc; $n=2)$, palindromic RA ( $\mathrm{n}=1)$, spondylarthritis $(\mathrm{n}=1)$, systemic vasculitis $(n=1)$, tendinitis $(n=1)$ and primary Sjögren's syndrome (PSS; $n=1$ ). Diagnoses were based on clinical signs and symptoms, as well as laboratory and radiological findings. Patients with incomplete or uncertain diagnosis were not included. 
The 325 non-rheumatic controls in the first set were recruited from the hospitals where the RA cases were recruited and comprised voluntary individuals who accompanied the patients and hospital staff $(\mathrm{n}=286)$, and patients without any autoimmune diseases (dengue fever patients, $\mathrm{n}=10$ and cardiovascular disease patients, $\mathrm{n}=$ 29). We used a common control group by pooling the rheumatic controls and non-rheumatic controls when comparing the diagnostic utility of RF and anti-CCP antibodies for RA. Only the healthy controls $(n=286)$ were used for the adjustment of the IgG and IgM RF cutoffs according to the 1987 ACR criteria [6], which defines $>95 \%$ specificity compared to healthy controls. The study was approved by the Medical Research and Ethics Committee, Ministry of Health, Malaysia. All the participants were informed about the research, and written consents were obtained.

\section{Laboratory Methods}

Anti-CCP antibodies were measured using the anti-CCP second generation enzyme-linked immunosorbent assay (ELISA) kits (Immunoscan RA Mark 2, Euro-Diagnostica, Malmö, Sweden). Samples with results $<25 \mathrm{U} / \mathrm{mL}$ were defined as negative. IgG and IgM RF were determined by IBL-rf_AGM ELISA kits (IBL, Hamburg. Germany). The analysis of IgG RF poses inherent technical problems not applicable to other RF isotypes. If human IgG is used for coating, the detection anti-human IgG antibody will not only detect the bound IgG RF, but also the coating antigen. In the present study, the RF assay kits used the highly purified Fc fragment of human immunoglobulin (IgG) for coating according to the manufacturer. In the initial evaluation, samples with results $\leq 15 \mathrm{IU} / \mathrm{ml}$ were defined as negative according to the manufacturer's recommendations. If the preceding evaluations, Malaysian-adjusted cutoffs were then established as the 96th percentile of Malaysian healthy controls according to the 1987 ACR classification criteria which request $>95 \%$ specificity as compared to healthy controls (the newly adjusted-cutoffs were $12 \mathrm{IU} / \mathrm{ml}$ for IgM RF and $20 \mathrm{IU} / \mathrm{ml}$ for IgG RF). All assays were performed according to the manufacturer's instructions.

\section{Statistics}

$\chi^{2}$-test (and Fisher's exact test when appropriate) was used to compare proportions. Mann-Whitney's U test was used to compare autoantibody levels in seropositive subjects from the three ethnic groups. Sensitivity and specificity were expressed in percentages. To evaluate the overall diagnostic utilities of serological markers for RA, the diagnostic accuracy was calculated as ([number of test-positive RA subjects] + [number of test-negative subjects in control groups])/(total number of subjects in the RA and control groups). When used according to the manufacturer's instructions, the anti-CCP2 kits employed do not deliver quantitative data below the company-defined cutoff, and the assumption of a linear relationship between $0 \mathrm{U} / \mathrm{ml}$ and $25 \mathrm{U} / \mathrm{ml}$ has been used to calculate the quantitative values for anti-CCP $<25 \mathrm{U} / \mathrm{ml}$, both in cases and controls, in order to perform ROC analyses. Statistical analyses have been conducted using SPSS 20.0 statistical software. ROC curves were constructed using the MedCalc software.

\section{Results}

\subsection{Prevalence of Autoantibodies in RA, Other Rheumatic Diseases and Non-Rheumatic Controls}

The overall prevalence of IgG RF was 55.6\% among RA cases, but also noticeable high among rheumatic (25.0\%) and non-rheumatic controls (5.8\%; Table 2). The prevalence of IgM RF was $36.8 \%, 10 \%$ and $2.8 \%$ in RA, other rheumatic diseases and non-rheumatic controls, respectively. After adjusting the cutoff to $20 \mathrm{IU} / \mathrm{ml}$ for IgG RF and $12 \mathrm{IU} / \mathrm{ml}$ for IgM RF, respectively (the 96th percentile of the 286 geographically matched healthy subjects according to the 1987 ACR criteria [6]), the increase IgG RF positivity was still apparent (46.6\%) in comparison with 40.4\% IgM RF-positive RA cases (Table 3).

Anti-CCP was detected in 98 of 171 (57.3\%) patients with RA, comparable to IgG RF. Three of $60(5.0 \%)$ patients in other rheumatic diseases and 7 of 325 (2.3\%) non-rheumatic controls were anti-CCP positive.

IgM RF was found in $32.3 \%$ of RA patients with disease duration $<2$ years, and in $48.9 \%$ of patients with long-standing disease, a difference reaching borderline significance $(p=0.044)$. For the other investigated autoantibodies there were no significant differences between patients with short and long disease duration. There were also no differences in proportions of autoantibodies between patients with and without radiographic erosions (data not shown).

In agreement with a number of earlier studies, the specificity of anti-CCP (97.1\%) was superior to that of IgG RF (91.2\%) and IgM RF (96.1\%), in the first set of RA cases compared to the combined control groups. To evaluate the overall diagnostic utility of serological markers for RA, the diagnostic accuracy was calculated. The diagnostic accuracy was highest for anti-CCP, intermediate for IgG RF and lowest for IgM RF (Table 3).

\subsection{Replication Study}

We performed the autoantibody measurements in the second set to replicate the findings of increased IgG 
Table 2. The number and percentage of patients with RA, and other rheumatic diseases, and non-rheumatic controls with positive titer for anti-CCP, IgG RF and IgM RF.

\begin{tabular}{|c|c|c|c|c|}
\hline Diagnosis & All & IgG RF positive (\%) & IgM RF positive (\%) & Anti-CCP positive (\%) \\
\hline \multicolumn{5}{|l|}{ Rheumatoid arthritis (RA) (\% sensitivity) } \\
\hline Initially investigated cohort (first set) & 171 & $95(55.5)$ & $63(36.8)$ & $98(57.3)$ \\
\hline Replication cohort (second set) & 886 & $471(53.2)$ & $457(51.6)$ & $581(65.6)$ \\
\hline Other rheumatic diseases (total) & 60 & $15(25.0)$ & $6(10.0)$ & $3(5.0)$ \\
\hline SLE & 28 & $6(21)$ & $2(7)$ & $0(0)$ \\
\hline Psoriatic arthritis & 9 & $4(44.4)$ & $1(11.1)$ & $1(11.1)$ \\
\hline Osteoarthritis & 8 & $0(0)$ & $0(0)$ & $0(0)$ \\
\hline Gouty arthritis & 3 & $1(33.3)$ & $0(0)$ & $0(0)$ \\
\hline MCTD & 3 & $1(33.3)$ & $1(33.3)$ & $0(0)$ \\
\hline Reactive arthritis & 2 & $0(0)$ & $0(0)$ & $0(0)$ \\
\hline Scleroderma & 2 & $2(100)$ & $1(50.0)$ & $1(50.0)$ \\
\hline Palindromic rheumatism & 1 & $0(0)$ & $0(0)$ & $0(0)$ \\
\hline Spondyloarthritis & 1 & $0(0)$ & $0(0)$ & $0(0)$ \\
\hline Systemic vasculitis & 1 & $0(0)$ & $0(0)$ & $0(0)$ \\
\hline Tendinitis & 1 & $0(0)$ & $0(0)$ & $0(0)$ \\
\hline Primary Sjögren’s syndrome & 1 & $1(100)$ & $1(100)$ & $1(100)$ \\
\hline \multicolumn{5}{|l|}{ Non-rheumatic controls } \\
\hline Initially investigated cohort (first set) & 325 & $19(5.8)$ & $9(2.8)$ & $7(2.3)$ \\
\hline Replication cohort (second set) & 958 & $73(7.6)$ & $44(4.6)$ & $27(2.8)$ \\
\hline $\begin{array}{l}\text { Healthy individuals among } \\
\text { non-rheumatic controls (first set) }\end{array}$ & 286 & 17 (5.9) & $8(2.3)$ & $6(2.1)$ \\
\hline All rheumatic and non-rheumatic controls (first set) & 385 & $34(8.8 \%)$ & $14(3.6 \%)$ & $10(2.6 \%)$ \\
\hline Overall specificity (first set) & - & $91.2 \%$ & 96.1 & $97.1 \%$ \\
\hline
\end{tabular}

RA: rheumatoid arthritis; anti-CCP: anti-cyclic citrullinated peptides; RF: rheumatoid factor; SLE: systemic lupus erythermatosus; MCTD: mixed connective tissue disease.

Table 3. Occurrence of IgG RF, IgM RF, anti-CCP autoantibodies in three Asian ethnic groups with RA.

\begin{tabular}{|c|c|c|c|c|c|c|c|c|c|c|c|c|c|}
\hline \multirow[b]{2}{*}{ Tests } & \multicolumn{4}{|c|}{ All RA patients $(\mathrm{n}=171)$} & \multicolumn{3}{|c|}{ Malay RA patients $(\mathrm{n}=92)$} & \multicolumn{6}{|c|}{ Chinese RA patients $(\mathrm{n}=31)$ Indian RA patients $(\mathrm{n}=39)$} \\
\hline & $\begin{array}{l}\text { Sensitivity } \\
(\%)\end{array}$ & $\begin{array}{l}\text { Specificity } \\
(\%)^{*}\end{array}$ & AUC & $\begin{array}{l}\text { Diagnostic } \\
\text { Accuracy } \\
\text { (\%) }\end{array}$ & $\begin{array}{l}\text { Sensitivity } \\
\text { (\%) }\end{array}$ & $\begin{array}{l}\text { Specificity } \\
(\%)^{*}\end{array}$ & AUC & $\begin{array}{l}\text { Sensitivity } \\
\text { (\%) }\end{array}$ & $\begin{array}{l}\text { y Specificity } \\
(\%)^{*}\end{array}$ & AUC & $\begin{array}{l}\text { Sensitivit } \\
(\%)\end{array}$ & $\begin{array}{l}\text { y Specificity } \\
(\%)^{*}\end{array}$ & AUC \\
\hline IgG RF & 55.6 & 91.2 & 0.826 & 80.2 & 57.6 & 91.2 & 0.825 & 61.3 & 91.2 & 0.881 & 48.7 & 91.2 & 0.803 \\
\hline $\begin{array}{l}\text { IgG RF } \\
\text { (ACR cutoff) }\end{array}$ & $\left(46.6^{* *}\right)$ & - & - & - & $\left(46.7^{* *}\right)$ & - & - & $\left(51.6^{* *}\right)$ & - & - & $\left(41.0^{* *}\right)$ & - & - \\
\hline IgM RF & 36.8 & 96.1 & 0.737 & 77.9 & 35.9 & 96.1 & 0.718 & 45.2 & 96.1 & 0.768 & 38.5 & 96.1 & 0.774 \\
\hline $\begin{array}{l}\text { IgM RF } \\
\text { (ACR cutoff) }\end{array}$ & $\left(40.4^{* * *}\right)$ & - & - & - & $\left(38.0^{* * *}\right)$ & - & - & $\left(51.6^{* * *}\right)$ & - & - & $\left(43.6^{* * * *}\right)$ & - & - \\
\hline Anti-CCP & 57.3 & 97.1 & 0.867 & 85.1 & 53.3 & 97.1 & 0.873 & 61.3 & 97.1 & 0.869 & 61.5 & 97.1 & 0.874 \\
\hline
\end{tabular}

AUC: Area under curve; ${ }^{*}$ All groups were compared to the same control group, as detailed in Materials and Methods. ${ }^{* *}$ After adjustment for the cutoff to 20 $\mathrm{IU} / \mathrm{mL}$, the 96th percentile for the 286 healthy controls, according to 1987 ACR criteria (6). ${ }^{* * *}$ After adjustment for the cutoff to 12 IU/mL, the 96 th percentile for the 286 healthy controls, according to 1987 ACR criteria (6). 
RF-positive found in the first set, using independent serum samples from $886 \mathrm{RA}$ cases and 958 control subjects. Also in this study, which in contrast to the first set consisted mainly $(>95 \%)$ of early RA cases $(<2$ years of symptom at diagnosis), more patients were positive for IgG RF (53.2\%) than for IgM RF (51.6\%; Table 4).

\subsection{Superiority of IgG RF over IgM RF in All Three Ethnic RA Populations}

When patients were stratified according to ethnicity, the proportions of autoantibody positive RA cases did not differ significantly for IgG or IgM RF between any of the three ethnic groups, and the higher sensitivity for IgG RF

Table 4. Occurrence of RF isotypes and anti-CCP in different published studies, grouped after geographical descent.

\begin{tabular}{|c|c|c|c|c|c|c|c|c|c|c|c|}
\hline Paper & $\begin{array}{l}\text { Geographical } \\
\text { descent }\end{array}$ & $\begin{array}{l}\text { RA } \\
\text { patients } \\
\text { (n, \% } \\
\text { females) }\end{array}$ & $\begin{array}{l}\text { IgA RF } \\
\text { (\%) }\end{array}$ & $\begin{array}{l}\text { IgG RF } \\
(\%)\end{array}$ & $\begin{array}{l}\text { IgM RF } \\
\text { (\%) }\end{array}$ & $\begin{array}{l}\text { Anti-CCP } \\
\text { (\%) }\end{array}$ & $\begin{array}{l}\text { Healthy }(H) \\
\text { or disease }(D) \\
\text { controls (n, } \% \\
\text { females) }\end{array}$ & $\begin{array}{l}\text { IgA RF } \\
(\%)\end{array}$ & $\begin{array}{l}\text { IgG RF } \\
(\%)\end{array}$ & $\begin{array}{l}\text { IgM RF } \\
(\%)\end{array}$ & $\begin{array}{l}\text { Anti-CCP } \\
(\%)\end{array}$ \\
\hline \multicolumn{12}{|l|}{$\begin{array}{l}\text { Caucasian } \\
\text { populations }\end{array}$} \\
\hline $\begin{array}{l}\text { Vallbracht, } \\
2004 \text { [9] }\end{array}$ & Germany & $295,80.3$ & $\begin{array}{l}150 \\
(50.8)\end{array}$ & $\begin{array}{l}129 \\
(43.7)\end{array}$ & $196(66.4)$ & $190(64.4)$ & H154, 54.5 & $7(4.5)$ & $7(4.5)$ & $11(7.1)$ & $1(0.6)$ \\
\hline $\begin{array}{l}\text { Jonsson, } \\
1998 \text { [8] }\end{array}$ & Iceland & 70,79 & $42(60)$ & $31(44)$ & $50(71)$ & - & D 205, 85 & $14(7)$ & $24(12)$ & $14(7)$ & - \\
\hline $\begin{array}{l}\text { Nell-Duxneuner, } \\
2010 \text { [26] }\end{array}$ & Austria & $200^{*}, 73$ & (29) & (14) & $(45)^{* * *}$ & (41) & - & - & - & - & - \\
\hline \multicolumn{12}{|l|}{$\begin{array}{l}\text { African } \\
\text { American }\end{array}$} \\
\hline $\begin{array}{l}\text { Mikuls, } \\
2006 \text { [25] }\end{array}$ & $\begin{array}{l}\text { USA (African } \\
\text { Americans) }\end{array}$ & 195, 81 & (65) & (39) & (70) & (62) & $\begin{array}{l}\text { H87, } 82 \\
\text { D97, } 90\end{array}$ & $(5)^{* * * *}$ & $(5)^{* * *}$ & $(5)^{* * *}$ & $11(6)$ \\
\hline $\begin{array}{l}\text { Singwe-Ngandedu } \\
\text { [27] }\end{array}$ & $\begin{array}{l}\text { African } \\
\text { (Cameroon) }\end{array}$ & 56,95 & 47 (84) & - & $43(77)$ & $46(82)$ & H51 & $0(0)$ & - & $4(8)$ & \\
\hline \multicolumn{12}{|l|}{$\begin{array}{l}\text { Asian } \\
\text { populations }\end{array}$} \\
\hline $\begin{array}{l}\text { Singh, } \\
2010[24]\end{array}$ & India & 119, 85.7 & \multicolumn{2}{|c|}{44 (36.9)50 (42) } & 57 (47.9) & $46\left(50^{* * * * *}\right.$ & H26 & $0(0)$ & $1(3.8)$ & $0(0)$ & $0(0)$ \\
\hline $\begin{array}{l}\text { Ahmed, } \\
2010 \text { [17] }\end{array}$ & Iraq & 53, 88.7 & $(41.5)$ & (83) & $(62.3)$ & - & - & - & - & - & - \\
\hline $\begin{array}{l}\text { Gomez, } \\
2011 \text { [19] }\end{array}$ & Malaysia & $147,87.8$ & 31 (21.1) & )71 (48.3) & 78 (53.1) & $100(68.0)$ & - & - & - & - & - \\
\hline Idem Malay & & 45, 93.3 & $8(17.8)$ & $27(60.0)$ & $28(62.2)$ & 33 (73.3) & - & - & - & - & - \\
\hline Idem Chinese & & 50,82 & $9(18.0)$ & $23(46.0)$ & $26(52.0)$ & $33(66.0)$ & - & - & - & - & - \\
\hline Idem Indian & & $52,88.5$ & 14 (26.9) & $21(40.4)$ & $24(46.2)$ & $34(65.4)$ & - & - & - & - & - \\
\hline $\begin{array}{l}\text { Initial study } \\
\text { (First set) }\end{array}$ & Malaysia & $171,87.7$ & - & 95 (55.6) & 63 (36.8) & $98(57.3)$ & $\begin{array}{l}\text { H325, } 84 \\
\text { D60. } 81.7\end{array}$ & - & 34 (8.8) & 15 (3.9) & $10(2.6)$ \\
\hline Idem Malay & & 92, 82.6 & - & $53(57.6)$ & 33 (35.9) & 49 (53.3) & & - & - & - & - \\
\hline Idem Chinese & & $31,77.4$ & - & 19 (61.3) & $15(45.2)$ & 19 (61.3) & & - & - & - & - \\
\hline Idem Indian & & 39, 92.3 & - & 19 (48.7) & 15 (38.5) & $24(61.5)$ & & - & - & - & - \\
\hline $\begin{array}{l}\text { Malaysia-adjusted } \\
\text { ACR } 1987 \text { cutoffs }\end{array}$ & & $171,87.7$ & - & $\begin{array}{l}79 \\
(46.6)^{* * * * * *}\end{array}$ & $\begin{array}{l}69 \\
(40.4)^{* * * * * *}\end{array}$ & & Н325, 84 & - & $9(4)$ & $8(4)$ & - \\
\hline $\begin{array}{l}\text { Replication study } \\
\text { (Second set) }\end{array}$ & Malaysia & $886,84.9$ & - & $\begin{array}{l}471 \\
(53.2)\end{array}$ & $\begin{array}{l}457 \\
(51.6)\end{array}$ & $581(65.6)$ & H958, 89.9 & - & 73 (7.6) & $44(4.6)$ & $27(2.8)$ \\
\hline Idem Malay & & $355,84.8$ & - & $\begin{array}{l}180 \\
(50.7)\end{array}$ & $\begin{array}{l}173 \\
(48.7)\end{array}$ & $224(63.1)$ & & - & $44(7.3)$ & $26(4.3)$ & $18(3.0)$ \\
\hline Idem Chinese & & $191,84.3$ & - & $96(50.3)$ & 96 (50.3) & $126(66.0)$ & & - & $9(7.4)$ & $3(2.5)$ & $3(2.5)$ \\
\hline Idem Indian & & $278,84.3$ & - & $\begin{array}{l}155 \\
(55.8)\end{array}$ & $\begin{array}{l}162 \\
(58.3)\end{array}$ & 186 (66.9) & & - & $15(8.4)$ & $11(6.2)$ & $4(2.2)$ \\
\hline
\end{tabular}

${ }^{*}$ Early arthritis. ${ }^{* *} 45 \%$ IgM RF positive using cutoffs $50 \mathrm{IU} / \mathrm{ml}$; 55\% IgM RF positive using cutoffs $20 \mathrm{IU} / \mathrm{ml}$ [30]. ${ }^{* * *}$ Calculated as 95th percentile of the control groups. ${ }^{* * * *} 92$ patients investigated for anti-CCP. ${ }^{* * * * *}$ Calculated as 96th percentile of the healthy control groups. 
as compared to IgM RF was evident among Malay, Chinese and Indian RA cases. For the Chinese RA patients the same sensitivity (61.3\%) was found both for IgG RF and anti-CCP (Table 3). There was however, no difference in autoantibody levels when the RA cases with a positive test result for IgG RF, IgM RF or anti-CCP were compared between the ethnic groups (data not shown).

For the comparison of the diagnostic utility of each marker in RA, we additionally undertook ROC analyses, and calculated the areas under the curves (AUC; Figure 1 and Table 3). The overall AUC of anti-CCP (0.867) was rather similar to IgG RF (0.826) but considerably higher than for IgM RF (0.737). When individual ROCcurves were constructed for the three ethnic groups of RA cases, the finding of a generally higher AUC value of IgG RF as compared to IgM RF could be demonstrated in all three ethnic groups. For the Chinese RA cases the AUC for IgG RF even surpassed the AUC value for antiCCP. AUC values for the individual ROC curves are detailed in Table 3.

\subsection{Occurrence of Anti-CCP in RF-Negative RA}

We also evaluated the utility of anti-CCP in RF-negative RA. Overall, anti-CCP was detected in $38.2 \%$ and $22.4 \%$ IgM RF and IgG RF-negative RA cases, respectively. Anti-CCP was found in more than $35 \%$ of the IgM RF-negative RA among all ethnic groups, and the corresponding figures were lower for IgG RF-negative RA cases in all the investigated ethnic groups, again stressing the difference between IgM and IgG RF in these Asian populations (Table 5).

\section{Discussion}

The diagnostic and prognostic values of anti-CCP antibody determination, alone or associated with RFs have been evaluated carefully [17-22], but the distribution of seroprevalence across different populations has not been reported. The present study shows that the presence IgG RF-positive RA cases were consistently higher than the occurrence of IgM RF in all three investigated ethnic groups with RA in Malaysia. Also, in a replication study involving early RA cases, IgG RF was more common than IgM RF (53.2\% versus 51.6\%). We also compared with previous studies which have displayed data showing IgG RF levels higher or close to IgM RF levels in other Asian RA populations (Table 4).

Significant differences exist among RF test kits and the reliability of some assays is questionable [23]. When RF isotype kits from the same manufacturer used in this study was assessed in a study of 295 German RA cases, the awaited IgM RF preponderance commonly seen in Caucasian studies was evident (IgM RF 66.4\%, IgA RF

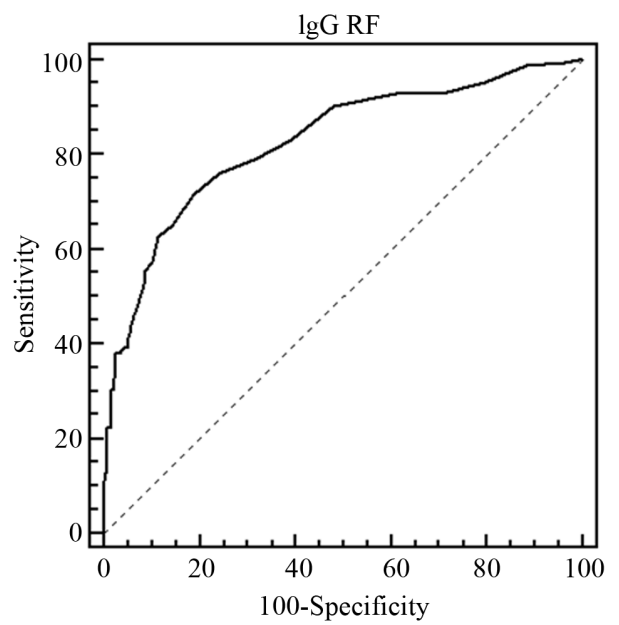

(a)

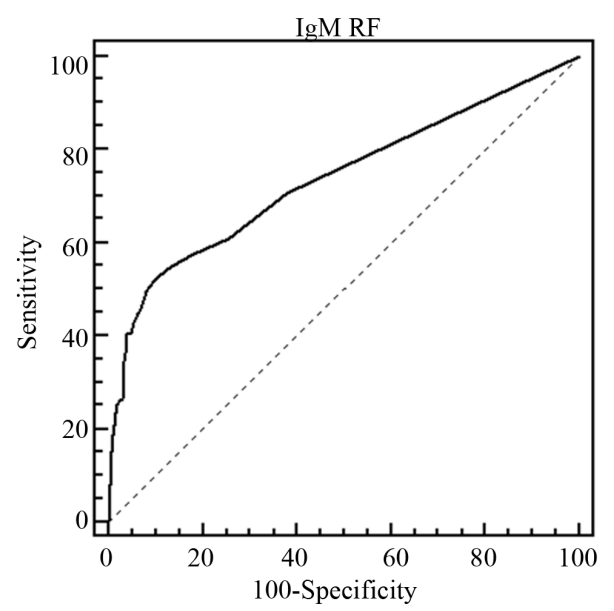

(b)

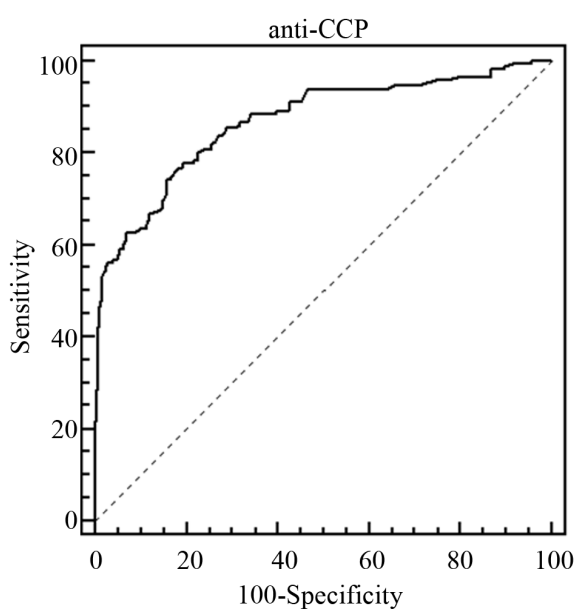

(c)

Figure 1. The receiver operator characteristic (ROC) curves for IgG RF, IgM RF and anti-CCP autoantibodies in the diagnosis of RA in Malaysian population. (a) IgG RF with area under ROC curve of 0.826; (b) IgM RF with area under ROC curve of 0.737 ; and (c) anti-CCP with area under ROC curve of 0.867 . 
Table 5. The occurrence of anti-CCP antibodies among IgG RF-negative or IgM RF-negative RA patients.

\begin{tabular}{lll}
\hline $\begin{array}{l}\text { Anti-CCP-positive } \\
\text { RA patients }\end{array}$ & $\begin{array}{l}\text { Anti-CCP-positive } \\
\text { and IgM RF-ngative } \\
\text { RA patients, n (\%) }\end{array}$ & $\begin{array}{l}\text { Anti-CCP-positive } \\
\text { and IgG RF-negative } \\
\text { RA patients, n (\%) }\end{array}$ \\
\hline All (n = 98) & $39(39.8)$ & $22(22.4)$ \\
Malay ( $=49)$ & $19(38.8)$ & $8(16.3)$ \\
Chinese ( $=19)$ & $5(35.7)$ & $3(15.8)$ \\
Indian ( $=24)$ & $10(41.7)$ & $8(33.3)$ \\
Mixed ethnicity $(\mathrm{n}=6) 5(83.3)$ & $3(50.0)$ \\
\hline
\end{tabular}

RA: rheumatoid arthritis; anti-CCP: anti-cyclic citrullinated peptides; RF: rheumatoid factor.

$50.8 \%$ and IgG RF 43.7\%) [9], with data very similar to those obtained in other studies performed in European RA populations (Table 4), thus ruling out any inconsistency in the behavior of the diagnostic laboratory reagents used in our investigation.

In all Asian studies where three RF isotypes have been investigated, the lowest sensitivities are described for IgA RF, with considerably higher or comparable sensitivities both for IgM RF and IgG RF. An example of a strong predominance of IgG RF (83\%) over IgM (62\%) and IgA RF (42\%) in Iraqi RA patients was reported by Ahmed and coworkers [17]. In a study on Indian RA patients IgG RF was almost as common as IgM RF (42\% vs $48 \%$ ), whereas IgA RF has a lower sensitivity (37\%) [24]. Very recently, a somewhat smaller Malaysian study showed a frequency for IgG RF-positive that almost equaled the frequency for IgM RF-positive (48.3\% vs. $53.1 \%$ ), whereas only $21.1 \%$ were IgA RF-positive [19]. In contrast, all studies on non-Asian RA populations show the maximal sensitivity for IgM RF, followed by IgA RF and with the lowest sensitivities for IgG RF $[8,9,25,26]$. Intriguingly, while data on African American RA patients from the USA show figures similar to the European data (RF positivity: IgM RF > IgA RF > IgG RF) [25], Singwe-Ngandeu et al. reported higher prevalence of IgA RF (84\%) followed by IgM RF (77\%) in 56 African RA patients living in Cameroon [27]. Thus, our current findings and the differences in RF isotypes distribution observed in African RA patients living both in the USA and Cameroon arguing for an environmental factor triggering RF isotype distribution.

The pathological significance of IgG RF is uncertain. In Swedish pre-RA patients, where especially IgA RF appears years before the onset of RA, IgG and IgM RF appear much later $[22,28]$. This is in contrast to pre-SLE patients, where elevated pre-SLE IgG RF is more closely associated to the later appearance of arthritis, and also appears earlier than IgM RF [29]. In that study, IgA RF was not investigated.

The limitation of our present study is the lack of data on IgA RF. Our choice of which RF isotypes to investigate in both the first and second study set was influenced by earlier experience from routine investigations of Malaysian RA patients. Although we have found it useful to investigate IgM RF and IgG RF but not IgA RF, the preponderance of IgG RF in Asia, both as compared to other RF isotypes in the same RA populations, and as compared to IgG RF in non-Asian populations, has not been highlighted before. In future studies of RF isotype distributions in Malaysia we intend to also include IgA RF.

\section{Conclusion}

In conclusion, our findings imply a possible equally important role of IgG RF and IgM RF in all the three ethnic groups of Malaysian RA patients. This finding, together with earlier studies which also show high levels of IgG $\mathrm{RF}$ in different Asian and Iraqi RA populations but not in RA populations from Europe or in African Americans or in Cameroon Africans, imply the existence of environmental factor(s) which may promote the development of IgG RF in Asia, especially in RA populations.

\section{Acknowledgements}

The authors would like to thank the Director General of Health, Ministry of Health, Malaysia for supporting the work described in this paper and permission to publish this paper. We are indebted to patients and controls for their kind participation. The authors also thank Nor Asiah Muhamad, Noraini Abdullah, Kee Chee Keong, Kasthoori Supramaniam, Hanjeet Kaur, Amal Nasir Mustafa, Maizun Mohd Zain, Masita Arip, Fatimah Karmila Abu Bakar, Ahneez Abdul Hameed, Norhazlin Mustafa, Ainur Yusniza for the collection of data, Eashwary Mageswaran, Muhaini Othman and Azmillah Rosman for practical help and assistance at the hospitals, Irda Yasmoon Awang, Salawati Mansor and Lee Yin Yin for their technical assistance in the laboratory and at site. This study was supported by the Ministry of Health (MoH), Malaysia: MRG 7/2005, IMR/PK/05/061 and JPP-IMR 08-012.

\section{REFERENCES}

[1] J. P. Riedemann, S. Munoz and A. Kavanaugh, "The Use of Second Generation Anti-CCP Antibody (Anti-CCP2) Testing in Rheumatoid Arthritis-A Systematic Review,” Clinical and Experimental Rheumatology, Vol. 23, No. 5, 2005, pp. S69-S76.

[2] S. Nijenhuis, A. J. Zendman, E. R. Vossenaar, G. J. Pruijn and W. J. vanVenrooij, "Autoantibodies to Citrullinated Proteins in Rheumatoid Arthritis: Clinical Per- 
formance and Biochemical Aspects of an RA-Specific Marker,” Clinica Chimica Acta, Vol. 350, No. 1, 2004, pp. 17-34. http://dx.doi.org/10.1016/j.cccn.2004.07.016

[3] W. J. van Venrooij, E. R. Vossenaar and A. J. Zendman, "Anti-CCP Antibodies: The New Rheumatoid Factor in the Serology of Rheumatoid Arthritis," Autoimmunity Reviews, Vol. 3, Suppl. 1, 2004, pp. S17-S19.

[4] G. A. Schellekens, H. Visser, B. A. de Jong, F. H. van den Hoogen, J. M. Hazes, F. C. Breedveld, et al., "The Diagnostic Properties of Rheumatoid Arthritis Antibodies Recognizing a Cyclic Citrullinated Peptide,” Arthritis \& Rheumatology, Vol. 43, No. 1, 2000, pp. 155-163. http://dx.doi.org/10.1002/1529-0131(200001)43:1<155:: AID-ANR20>3.0.CO;2-3

[5] J. J. Cush, "Early Arthritis Clinics: If You Build It Will They Come?” Journal of Rheumatology, Vol. 32, No. 2, 2005, pp. 203-207.

[6] F. C. Arnett, S. M. Edworthy, D. A. Bloch, D. J. McShane, J. F. Fries, N. S. Cooper, et al., "The American Rheumatism Association 1987 Revised Criteria for the Classification of Rheumatoid Arthritis," Arthritis \& Rheumatology, Vol. 31, No. 3, 1988, pp. 315-324. http://dx.doi.org/10.1002/art.1780310302

[7] U. M. Nowak and M. M. Newkirk, "Rheumatoid Factors: Good or Bad for You?” International Archives of Allergy and Immunology, Vol. 138, No. 2, 2005, pp. 180-188. http://dx.doi.org/10.1159/000088794

[8] T. Jonsson, K. Steinsson, H. Jonsson, A. J. Geirsson, J. Thorsteinsson and H. Valdimarsson, "Combined Elevation of IgM and IgA Rheumatoid Factor Has High Diagnostic Specificity for Rheumatoid Arthritis,” Rheumatology International, Vol. 18, No. 3, 1998, pp. 119-122. http://dx.doi.org/10.1007/s002960050069

[9] I. Vallbracht, J. Rieber, M. Oppermann, F. Forger, U. Siebert and K. Helmke, "Diagnostic and Clinical Value of Anti-Cyclic Citrullinated Peptide Antibodies Compared with Rheumatoid Factor Isotypes in Rheumatoid Arthritis," Annals of the Rheumatic Diseases, Vol. 63, No. 9, 2004, pp. 1079-1084. http://dx.doi.org/10.1136/ard.2003.019877

[10] T. Jonsson, S. Arinbjarnarson, J. Thorsteinsson, K. Steinsson, A. J. Geirsson, H. Jonsson, et al., "Raised IgA Rheumatoid Factor (RF) but Not IgM RF or IgG RF Is Associated with Extra-Articular Manifestations in Rheumatoid Arthritis," Scandinavian Journal of Rheumatology, Vol. 24, No. 6, 1995, pp. 372-375. http://dx.doi.org/10.3109/03009749509095183

[11] F. C. Hay, L. J. Nineham, R. Perumal and I. M. Roitt, "Intra-Articular and Circulating Immune Complexes and Antiglobulins (IgG and IgM) in Rheumatoid Arthritis; Correlation with Clinical Features," Annals of the Rheumatic Diseases, Vol. 38, No. 1, 1979, pp. 1-7. http://dx.doi.org/10.1136/ard.38.1.1

[12] H. G. Kunkel, H. J. Muller-Eberhard, H. H. Fudenberg and T. B. Tomasi, "Gamma Globulin Complexes in Rheumatoid Arthritis and Certain Other Conditions,” Journal of Clinical Investigation, Vol. 40, No. 1, 1961, pp. 117129.
[13] D. A. Carson, S. Lawrance, M. A. Catalano, J. H. Vaughan and G. Abraham, "Radioimmunoassay of IgG and IgM Rheumatoid Factors Reacting with Human IgG," Journal of Immunology, Vol. 119, No. 1, 1977, pp. 295300.

[14] R. M. Pope, M. Mannik, B. C. Gilliland and D. C. Teller, "The Hyperviscosity Syndrome in Rheumatoid Arthritis Due to Intermediate Complexes Formed by Self-Association of IgG-Rheumatoid Factors," Arthritis \& Rheumatology, Vol. 18, No. 2, 1975, pp. 97-106. http://dx.doi.org/10.1002/art.1780180201

[15] D. Aletaha, T. Neogi, A. J. Silman, J. Funovits, D. T. Felson, C. O. Bingham, et al., "Rheumatoid Arthritis Classification Criteria: An American College of Rheumatology/European League against Rheumatism Collaborative Initiative," Annals of the Rheumatic Diseases, Vol. 69, No. 9, 2010, pp. 1580-1588. http://dx.doi.org/10.1136/ard.2010.138461

[16] T. Chun-Lai, L. Padyukov, J. S. Dhaliwal, E. Lundstrom, A. Yahya, N. A. Muhamad, et al., "Shared Epitope Alleles Remain a Risk Factor for Anti-Citrullinated Proteins Antibody (ACPA)-Positive Rheumatoid Arthritis in Three Asian Ethnic Groups,” PLoS One, Vol. 6, No. 6, 2011, Article ID: e21069. http://dx.doi.org/10.1371/journal.pone.0021069

[17] M. M. Ahmed, K. A. Obaid Al-Ruhaimi and S. H. Mohammed, "Evaluation of the Rheumatoid Factors of the IgG, IgM and IgA Isotypes as Prognostic Parameters for Rheumatoid Arthritis among Iraqi Patients," Indian Journal of Pathology and Microbiology, Vol. 53, No. 3, 2010, pp. 433-438. http://dx.doi.org/10.4103/0377-4929.68265

[18] N. A. Fathi, A. M. Ezz-Eldin, E. Mosad, R. M. Bakry, H. B. Hamed, S. Ahmed, M. Mahmoud, et al., "Diagnostic Performance and Predictive Value of Rheumatoid Factor, Anti-Cyclic-Citrullinated Peptide Antibodies and HLADRB1 Locus Genes in Rheumatoid Arthritis,” International Archives of Medicine, Vol. 1, No. 1, 2008, p. 20. http://dx.doi.org/10.1186/1755-7682-1-20

[19] E. L. Gomez, S. C. Gun, S. D. Somnath, B. D’Souza, A. L. Lim, K. Chinna, et al., "The Prevalence of Rheumatoid Factor Isotypes and Anti-Cyclic Citrullinated Peptides in Malaysian Rheumatoid Arthritis Patients," International Journal of Rheumatic Diseases, Vol. 14, No. 1, 2011, pp. 12-17. http://dx.doi.org/10.1111/j.1756-185X.2010.01573.x

[20] B. Heidari, A. Firouzjahi, P. Heidari and K. Hajian, “The Prevalence and Diagnostic Performance of Anti-Cyclic Citrullinated Peptide Antibody in Rheumatoid Arthritis: The Predictive and Discriminative Ability of Serum Antibody Level in Recognizing Rheumatoid Arthritis," Annals of Saudi Medicine, Vol. 29, No. 6, 2009, pp. 467470. http://dx.doi.org/10.4103/0256-4947.57170

[21] A. Kapitany, Z. Szabo, G. Lakos, M. Aleksza, A. Vegvari, L. Soos, et al., "Associations between Serum Anti-CCP Antibody, Rheumatoid Factor Levels and HLA-DR4 Expression in Hungarian Patients with Rheumatoid Arthritis," Israel Medical Association Journal, Vol. 10, No. 1, 2008, pp. 32-36.

[22] H. Kokkonen, M. Mullazehi, E. Berglin, G. Hallmans, G. 
Wadell, J. Ronnelid, et al., “Antibodies of IgG, IgA and IgM Isotypes against Cyclic Citrullinated Peptide Precede the Development of Rheumatoid Arthritis," Arthritis Research \& Therapy, Vol. 13, No. 1, 2011, p. R13. http://dx.doi.org/10.1186/ar3237

[23] S. Bas, T. V. Perneger, E. Kunzle and T. L. Vischer, "Comparative Study of Different Enzyme Immunoassays for Measurement of IgM and IgA Rheumatoid Factors," Annals of the Rheumatic Diseases, Vol. 61, No. 6, 2002, pp. 505-510. http://dx.doi.org/10.1136/ard.61.6.505

[24] U. Singh, A. Vishwanath, P. K. Verma, N. K. Singh, R. C. Shukla, S. Singh, et al., "Is Rheumatoid Factor Still a Superior Test for the Diagnosis of Rheumatoid Arthritis?” Rheumatology International, Vol. 30, No. 8, 2010, pp. 1115-1119.

http://dx.doi.org/10.1007/s00296-009-1338-0

[25] T. R. Mikuls, V. M. Holers, L. Parrish, K. A. Kuhn, D. L. Conn, G. Gilkeson, et al., "Anti-Cyclic Citrullinated Peptide Antibody and Rheumatoid Factor Isotypes in African Americans with Early Rheumatoid Arthritis," Arthritis \& Rheumatology, Vol. 54, No. 9, 2006, pp. 3057-3059. http://dx.doi.org/10.1002/art.22200

[26] V. Nell-Duxneuner, K. Machold, T. Stamm, G. Eberl, H. Heinzl, E. Hoefler, et al., “Autoantibody Profiling in Pa- tients with Very Early Rheumatoid Arthritis: A FollowUp Study," Annals of the Rheumatic Diseases, Vol. 69, No. 1, 2010, pp. 169-174. http://dx.doi.org/10.1136/ard.2008.100677

[27] M. Singwe-Ngandeu, A. Finckh, S. Bas, J. M. Tiercy and C. Gabay, "Diagnostic Value of Anti-Cyclic Citrullinated Peptides and Association with HLA-DRB1 Shared Epitope Alleles in African Rheumatoid Arthritis Patients," Arthritis Research \& Therapy, Vol. 12, No. 2, 2010, p. R36. http://dx.doi.org/10.1186/ar2945

[28] S. Rantapaa-Dahlqvist, B. A. de Jong, E. Berglin, G. Hallmans, G. Wadell, et al., "Antibodies against Cyclic Citrullinated Peptide and IgA Rheumatoid Factor Predict the Development of Rheumatoid Arthritis," Arthritis \& Rheumatology, Vol. 48, No. 10, 2003, pp. 2741-2749. http://dx.doi.org/10.1002/art.11223

[29] L. D. Heinlen, M. T. McClain, J. Merrill, Y. W. Akbarali, C. C. Edgerton, J. B. Harley, et al., "Clinical Criteria for Systemic Lupus Erythematosus Precede Diagnosis, and Associated Autoantibodies Are Present before Clinical Symptoms,” Arthritis \& Rheumatology, Vol. 56, No. 7, 2007, pp. 2344-2351.

http://dx.doi.org/10.1002/art.22665 